\title{
As vicissitudes do matar. Conflitos ontológicos em um estudo sobre leishmaniose tegumentar americana na TI Wajãpi
}

Reflections on killing. Ontological conflits over Cutaneus Leshimaniasis in Wajãpi Indigenous Land

Joana Cabral de Oliveira*

*Universidade Estadual de Campinas - Campinas, SP, Brasil jcdo@unicamp.br https://orcid.org/0000-0002-4308-8562 


\title{
Resumo
}

A partir de uma pesquisa sobre os padrões epidemiológicos de leishmaniose tegumentar americana na Terra Indígena Wajãpi (AP), tomo como ponto de partida as perspectivas de alguns Wajãpi e de cientistas para explorar aspectos das ontologias em disputas nesse contexto. Oscilando entre os diferentes sujeitos dessa pesquisa, pretendo refletir e descrever como cada um deles compreende questões comuns como: a matabilidade de alguns seres, as relações com diferentes níveis de alteridade e as perspectivas das relações interespecíficas.

Palavras-chave: etnologia; antropologia da ciência; relações interespecíficas; comparação.

\begin{abstract}
During an epidemiological research of cutaneous leshimaniasis in Wajãpi Indigenous Land, several ontological perspectives between scientific team and Wajãpi people happened. These ontological issues are the main material analyzed by this paper. Switching between different subjects, the paper aims to describe the perspectives of each subject answering what is possible or not to kill, the moral implications around the death of different beings and how interspecific relations are conceived.
\end{abstract}

Keywords: Amerindian ethnology; anthropology of science; interspecific relations; comparison. 
Pertencemos ao filo dos Chordata, dos animais dependurados sobre um cabide interno. Isto se manifesta existencialmente em todo o encontro nosso com outro animal: quando esmagamos sob nosso pé qualquer vida que contenha ossos que se partem, identificamo-nos com tal vida. Quando a vida esmagada é mole, sentimos nojo.

Vilém Flusser e Louis Bec (2011, p. 21)

\section{Provocações metodológicas ${ }^{1}$}

Um dos pilares da antropologia, que marca a constituição da disciplina e pode ser considerado mesmo sua identidade epistemológica, é a comparação. Para fins heurísticos apenas, Candea (2016) distingue duas modalidades dela: a comparação lateral e a frontal. A lateral seria aquela entre grupos não familiares ao antropólogo, que são justapostos em uma descrição com o objetivo de criar adensamentos que permitam afirmações para além do caso particular. A frontal é a comparação entre o grupo ao qual pertence o antropólogo e aquele por ele estudado.

Há tempos a comparação frontal é pauta de grandes elucubrações e críticas, um de seus pontos mais atacados é a consequente criação de um fosso entre Nós e Eles. A separação abissal entre Modernos e Não Modernos ou Ocidentais e Não Ocidentais. Um dos problemas notado por Candea, e de modo pioneiro por Strathern (2006), é que as etnografias de povos não familiares costumam apresentar o Ocidente Moderno como um bloco homogêneo que serve de fundo à entidade etnográfica, tornada figura por suas diferenças. Nesse procedimento, a posição ocupada pelo Nós (da qual faz parte o antropólogo e sua audiência) não precisa ser explicitada, já que é compartilhada e compreendida como óbvia. Já a posição do Eles é necessariamente esmiuçada, afinal é o polo que jaz nas sombras do desconhecimento.

1 Versões deste artigo foram apresentadas em dois eventos: "Quartas Indomáveis", da UFSCar, e "Quartas de Antropologia", da Unicamp. Agradeço aos colegas presentes por seus comentários e intervenções nessas ocasiões. Além disso, o artigo é resultado de uma pesquisa de pós-doutorado realizada no Instituto de Biociências da USP sob supervisão de Rui Murrieta, a quem sou grata. Agradeço imensamente, ainda, à Fapesp, que financiou a pesquisa (processo 2014/13089-2); aos Wajãpi, que me recebem em suas aldeias desde 2004; e aos meus colegas de pesquisa coletiva sobre padrões de transmissão de leishmaniose, que optaram por manter o anonimato. 
Contudo, a antropologia e outras ciências do social já demonstraram que ao aproximarmo-nos do bloco intitulado Ocidente ele rapidamente se fragmenta. Com uma mudança escalar da investigação, o que era monolítico se torna multivocal e repleto de matizes. Mas a comparação parece exigir alguma estabilização. Por isso uma das saídas, inaugurada por Strathern (2006), é realizar a comparação frontal alertando o leitor de que se trata de um dispositivo recursivo e momentâneo que visa criar contraste. Mas e se a diferença não é produzida? Segundo Candea (2016, p. 11) a comparação frontal falha ao resultar em similaridade. Ela falha ao gerar um efeito de reconhecimento entre entidades etnográficas radicalmente distintas, pois fundo e figura se tornam um.

Enfim, a grande questão sobre como proceder à comparação entre Nós e Eles paira. Se o problema está posto desde a fundação disciplinar, sua versão atualizada é como comparar sem reificar posições que são pronominais. Como comparar de modo a embaralhar fronteiras. Em suma, como comparar de maneira que nossas divisões sejam complicadas, uma vez que elas não se sustentam mais sobre sólidos solos.

Partindo do componente etnográfico que fomenta o presente artigo, muitas das línguas ameríndias e especificamente o wajãpi fazem uma diferenciação entre dois tipos de nós: um inclusivo (um nós que inclui a mim, meus convíveres e a quem eu falo - vocês que me leem) e um exclusivo (um nós que se refere apenas a mim e meus convíveres, excluindo, no caso, os leitores). Transpondo essa diferenciação ao problema da comparação antropológica que Candea nos desenha, o que farei a seguir é uma reflexão etnográfica a partir de um nós exclusivo. Trata-se de um nós que não inclui a audiência do texto e que, por isso, exige uma aproximação e um desmonte do dado a cada vez. A aposta é que o uso de um nós exclusivo permita o esfacelamento do monobloco Ocidente Moderno, possibilitando, às vezes, que o Nós e Eles se tornem similares diferindo daqueles que aqui nos leem, amalgamando nós e eles (por meio de um nós exclusivo) sem perder o efeito de produção de sentido que é dado pela diferença.

O uso do nós exclusivo possibilita aqui um relato sobre uma equipe de pesquisadores da qual faço parte e em que estou plenamente implicada. O que se segue portanto é uma descrição etnográfica complicada, ou melhor, co-implicada e por isso cheia de instabilidades e co-fusões (ou confusões) entre nós inclusivo e eles, e entre nós exclusivo e vocês. Por uma descrição complicada entendo, seguindo uma das definições do adjetivo, uma descrição "composta de 
elementos que entretêm relações numerosas, diversificadas e difíceis de apreender" (Houaiss, 2001, p. 777). Um título novo (talvez mais adequado à tarefa que se pretende enfrentar) para um gênero clássico - a etnografia.

Por outro lado, remeter aos dois nós de línguas ameríndias permite reverberar o caráter múltiplo de nosso pronome coletivo de primeira pessoa. Um nós conformado por diferentes eus, eles e vocês e que por isso pode e deve, a cada instante, ser desdobrado em suas diferenças internas. O leitor encontrará, assim, posições dissonantes desse nós compósito, as quais são pontuadas em nota de rodapé ou no corpo do texto; dissonâncias que são referidas por estratégia textual à formação majoritária de cada um dos membros dessa pesquisa.

\section{Um primeiro conflito ontológico}

O contexto dessa reflexão é o projeto multidisciplinar sobre os padrões epidemiológicos da leishmaniose tegumentar americana (LTA) na Terra Indígena Wajãpi (TIW), localizada no Amapá. O objetivo da equipe era estudar os determinantes ${ }^{2}$ socioambientais relacionados à doença, fornecendo subsídios para melhorar a prevenção e controle executados pelo serviço público de saúde indígena.

Antes de focar em alguns acontecimentos desenrolados no processo de pesquisa coletiva, irei recuperar um episódio de disputa ontológica que permite uma porta de entrada ao problema.

A equipe do projeto tinha como núcleo central uma entomóloga, uma veterinária, um epidemiologista à época trabalhando na Secretaria Especial de Saúde Indígena (Sesai) e eu como antropóloga. A presença de um membro ligado a uma agência federal de atuação na saúde fazia com que, por vezes, nos envolvêssemos em outras atividades que não aquelas exclusivas à pesquisa, e foi numa dessas ocasiões que ocorreu o acontecimento que servirá de primeiro mote.

2 Todo o artigo foi escrito em intenso diálogo e negociação com meus colegas cientistas de pesquisa. Por isso, muitas vezes se opta pelo uso de jargões de outras disciplinas, como ocorre com "determinantes", que é amplamente empregado na epidemiologia. A noção de que "determinantes" refere-se aos fatores ambientais, sociais, econômicos, culturais, étnicos/raciais, psicológicos e comportamentais que influenciam a ocorrência de problemas de saúde e seus fatores de risco na população (Galvão; Finkelman; Henao, 2011). Constantemente meus colegas de pesquisa apontaram para a necessidade de usar os seus termos e conceitos, como o uso de "determinantes" em vez de fatores, como havia optado em uma primeira versão. 
Entre os anos de 2013 e 2014 uma série de ataques de morcegos hematófagos a crianças e a animais domésticos tomaram lugar em algumas aldeias wajãpi, fazendo com que as famílias levassem o problema à Sesai. Sendo um importante hospedeiro do vírus da raiva, os morcegos alarmavam a todos. Acompanhei uma das empreitadas que visava coletar informações ${ }^{3}$ sobre $o$ problema. Segui para uma das aldeias com o epidemiologista ${ }^{4}$ e um especialista em Microchiroptera (subordem que inclui morcegos). Lá passamos duas noites capturando os mamíferos voadores e identificando os indivíduos pertencentes à espécie hematófaga, os quais eram untados com uma pasta vampiricida ${ }^{5}$ e soltos. Animais que possuem o hábito de dormirem em bando, em seu regresso após as saídas noturnas para alimentação, os morcegos se lambem uns aos outros. O uso dessa técnica permite, portanto, acabar com as colônias vampíricas.

Dezenas de morcegos foram capturados por longas "redes de neblina". ${ }^{6}$ Cada um deles era identificado, pesado e tinha amostra de sangue retirada (seriam

3 Sempre muito cuidadosa com as expectativas criadas em torno da eficácia dos trabalhos científicos e ações de saúde pública pautadas no conhecimento científico, bem como assumindo uma postura crítica sobre a abrangência do conhecimento e dos modos investigativos, a veterinária me alertou que tal procedimento só poderia ter como objetivo "trazer evidências sobre a circulação ou não do vírus da raiva e informações sobre composição da fauna de quirópteros, além de controle de morcegos hematófagos (segundo protocolo da Funasa) que poderiam ou não funcionar".

4 Cuja formação é em veterinária.

5 Uma das sugestões de meus parceiros de pesquisa foi utilizar o termo técnico, "pasta vampiricida", em vez de "veneno". Segundo se argumentou: "É uma hipocrisia, mas veneno é uma palavra que traz um efeito amador à história, não uma ação profissional, como foi." O método empregado segue as diretrizes legais estabelecidas pelo Ministério da Saúde e do Meio Ambiente, sendo a pasta vampiricida usada de modo seletivo na espécie vetor (Desmodus rotundus). A substância empregada é um anticoagulante que causa hemorragia generalizada levando à morte uma colônia desses animais. A solicitação de meus colegas demonstra uma preocupação com o modo como falamos da morte desses animais. Me parece que essa questão enunciativa aponta para os desdobramentos éticos envoltos nessas mortes. Ainda que a morte seja quimicamente violenta, ela ocorre longe dos olhos e da ação imediata dos profissionais que atuam no controle de zoonoses, assim como a preferência por termos técnicos parece distanciar e amenizar a ação. Mesmo sendo perpetrada com vista à preservação de vidas humanas, parece existir um ônus ético e moral em matar os morcegos, daí a necessidade de uma morte controlada ("seletiva" à espécie vetor), protocolar (seguindo padrões federais de conduta) e enunciada de maneira barroca (uso de jargão técnico que afastam o sentido da ação).

6 Redes usadas para captura de morcegos, que se assemelham às redes de pesca, mas são feitas de náilon preto. 
testados para raiva). Alguns dos hematófagos eram emplastrados com a pasta vampiricida e soltos, enquanto outros foram mortos e coletados para fins taxonômicos e de detecção de vírus. Alguns moradores do local observaram nossa atividade, mas logo se cansaram e foram deitar-se. No dia seguinte, o chefe da aldeia indagou ao epidemiologista porque eles soltavam os animais ao invés de matá-los. Arguia que nós deveríamos acabar com todos de uma só vez - em wajãpi dizia que era preciso wapisipa ("exterminá-los").? O epidemiologista explicou a técnica do veneno e, sobretudo, argumentou que a grande maioria dos morcegos capturados não eram hematófagos, alimentavam-se de frutas e eram importantes polinizadores; matá-los acarretaria um problema de ordem ecológica.

Várias famílias pediam para deixarmos o veneno e as malhas de captura, assim eles mesmos poderiam exterminar (wapisipa) todos os morcegos. A reação da equipe era sempre refratária. Temerosos com essa possibilidade, disparavam um discurso sobre a importância de um equilíbrio ecológico e da função desses animais em uma cadeia mais extensa de relações interespecíficas.

Demanda similar foi enfrentada no âmbito da pesquisa sobre leishmaniose. Uma das atividades centrais da pesquisa era a coleta de vetores - os flebotomíneos (mosquito-palha, na linguagem popular e mypiri em wajãpi). As fêmeas de flebótomos picam animais vertebrados que podem ${ }^{8}$ funcionar como reservatórios $^{9}$ do protozoário (a leishmânia) que opera no ciclo da doença. Note-se que é essa compreensão científica sobre a LTA que é tomada como ponto inicial,

7 É importante ter mente que o extermínio, aqui, está inserido em uma ontologia onde a condição de sujeito é amplamente distribuída, compartilhada por diferentes tipos de humanidade e entre não humanos. Isso significa que o extermínio é uma ação estabelecida entre sujeitos em disputas, sendo passível de retaliação. Isso se contrasta a uma concepção de extermínio tal qual em uma ontologia moderna, pautada na cisão entre sujeito e objeto, onde aqueles que são exterminados são objetificados, o que constitui um processo de violência unilateral.

8 O cuidado com a linguagem e a expressão das cadeias causais é algo importante e sobre o qual os meus colegas de pesquisa me chamaram atenção. Nem todo vertebrado funcionará como reservatório e é possível inclusive pensar que as características individuais de um organismo, cuja espécie é correntemente um reservatório, podem fazer com que um indivíduo não opere como hospedeiro. Daí a afirmação incorporar o verbo "poder", modalizando a proposição.

9 O conceito de reservatório é tanto individual, de características intrínsecas ao organismo, quanto ecológico, que inclui: densidades populacionais, sazonalidade, comportamentos, etc. 
a partir do qual os desdobramentos e interações aqui descritos são gerados, sem que, em certa medida, se altere ou questione ao longo dos encontros com as famílias wajãpi essa teoria biológica do ciclo da doença. ${ }^{10} \mathrm{~A}$ principal técnica de captura de vetores foi o uso de armadilhas luminosas, que atraem os insetos noturnos com uma fonte de luz e os suga para um pote coletor por um sistema de ventilação. Tais armadilhas foram postas em locais amostrais tidos como estratégicos: no meio, na borda e fora da aldeia, e nos caminhos para igarapés, roças ou trilhas de caça.

Mais de uma vez nos foi solicitado pelos moradores que deixássemos as armadilhas nas aldeias, assim poderiam matar todos os mypiri e jãsi'ü - os hematófagos transmissores dos agentes causadores de leishmaniose e malária. A resposta fornecida nesse caso era que algumas armadilhas não resolveriam o problema. ${ }^{11}$ Tais insetos são abundantes e estão por toda parte.

Se o desejo wajãpi era pelo extermínio completo desses seres outros, parte de nós ${ }^{12}$ apontava para uma ética da moderação ${ }^{13}$ e da necessidade de convivência via equilíbrio ecológico.

10 É interessante comentar que alguns Wajãpi apontaram um pequeno besouro como uma espécie relacionada à LTA, cuja mordida, segundo eles, leva ao aparecimento de feridas que o sistema médico diagnosticava como LTA. Contudo, esse aspecto nunca foi investigado, uma vez que os flebotomíneos são, segundo a ciência, comprovadamente os vetores da doença.

11 Segundo a veterinária o fato de não conseguirmos prever ou imaginar possíveis problemas ecológicos advindos do extermínio dos flebotomíneos não anula a existência desse efeito. Ainda assim, um artigo que explora essa possibilidade com diferentes pesquisadores (Fang, 2010) aponta que parte da comunidade científica não imagina que haveria grandes efeitos na maioria dos ecossistemas se os mosquitos fossem extintos. No caso dos flebotomíneos, que são muito pequenos (menor biomassa), os efeitos seriam ainda menores. Nossa veterinária, cautelosa, aponta para a complexidade dos sistemas ecológicos e sua consequente imprevisibilidade; distanciando-se de modelos mecânicos e fechados que parecem estar por trás da posição assumida por alguns pesquisadores no artigo de Fang.

12 Aqui enfrentamos uma controvérsia interna ao "nós". Um de nós lembra que boa parte da comunidade científica e atores da saúde pública insiste e almeja a erradicação da doença, defendendo que o extermínio do protozoário e dos vetores não traria qualquer tipo de consequência às comunidades humanas (legitimando-se em Fang, 2010). Contudo, outra parte de nós se acautela e aponta para os possíveis efeitos sistêmicos da extinção de flebótomos, dirigindo-se a uma ideia de equilíbrio ecológico que ecoa a possibilidade de convivência, posição também reconhecida por outros pesquisadores e lembrada com menor ênfase no mesmo artigo de Fang (2010).

13 Expressão que Gallois (1988) usa para falar da relação wajãpi com a caça, e que tomo de empréstimo para tratar a nossa posição nesse contexto. 


\section{Sobre inimigos wajãpi}

O termo usado em língua wajãpi para expressar o desejo de matar todos os morcegos e insetos hematófagos foi o verbo em sua forma conjugada owapisipa. Sua raiz -pisi significa guerra e o uso do completivo - $p a$ indica sua ação finalizada, completa, a qual opto por traduzir como "extermínio".

Gallois $(1988$, p. 84, 89), ao tratar das categorias de alteridade wajãpi, destaca um conjunto de inimigos denominados genericamente de ãpã, onde figuram grupos nominados (Warikenã, Karanã, Kariponã, Tapãã̃, etc.) cuja marca máxima de alteridade é o canibalismo (-poro’u e/ou -porosu’u):

Todos os inimigos são considerados canibais (-poro'u, quem nos come). De acordo com as narrativas e relatos, os apã roubavam crianças, mulheres ou rapazes que eram mortos e devorados, inteiros ou em pedaços. [...] A posição de alteridade máxima ocupada pelos inimigos no imaginário waiãpi é dada pela sua origem: via de regra, nascem de um - ou de uma série - de atos sexuais proibidos. A descrição de seu comportamento repugnante segue logicamente o mesmo fio: das preferências sexuais às alimentares, os inimigos distanciam-se da conduta humana pois, como faziam os Karipono, comem carne crua, bebem sangue de cobra, se deliciam com os órgãos sexuais dos homens capturados em guerra. [...] Se são tão temidos, é justamente porque praticam as duas formas de agressão canibal concebidas pelos Waiãpi: tanto devoram nossa carne (-poro'u), como bebem nosso sangue (-porosu'u).

Os relatos wajãpi de conflito com tais inimigos remetem a uma série de guerras (-pisi) que foram vencidas por eles, resultando no extermínio dos inimigos canibais. Segundo Gallois (1988, p. 84): "São todos relatos de guerra, em que os Waiãpi saem vencedores, após eliminarem seus inimigos, usando técnicas características da área das Guianas: fumaças tóxicas (folhas de palmeira e pimenta), fogo e ataques com bordunas (kaparu)." ${ }^{14}$ Adiante a autora remete a versões em que os Wajãpi, visando vingança, planejaram comer os inimigos:

14 Borduna é um arma, um porrete de madeira dura e pesada, feito para bater na cabeça de inimigos. 
Algumas narrativas indicam que os Waiãpi pretendiam revidar os atos canibais a que tinham sido submetidos: despedaçavam os corpos dos inimigos para moqueá-los e comê-los, mas terminaram preferindo jogar fora os pedaços de carne, que se transformaram em morcegos e mosquitos. Os restos desses inimigos, agora transformados, permanecem canibais, pois continuam nos mordendo e bebendo nosso sangue. (Gallois, 1988, p. 85).

Aqui chego ao ponto de conexão dessas narrativas sobre os inimigos e o conflito ontológico com o qual me deparei em 2014. O que os Wajãpi pareciam desejar fazer com os seres hematófagos (ou seja, os morcegos e os flebótomos) era replicar a ação de extermínio tal qual empreendida em tempos anteriores com alguns inimigos. Enquanto uma versão transformada dos inimigos canibais, os hematófagos exigem e são passíveis de uma ação de mesma ordem: owapisipa.

Algumas outras conexões parciais podem reforçar essa hipótese: em wajãpi se diz que morcegos e insetos hematófagos -porosu'u ("mordem", “chupam sangue'), ou seja, executam uma ação agressiva de canibalismo, o que os conecta à série de agressões xamânicas atuais, bem como às antigas guerras, e com os ãpã de maneira geral. Outra similaridade é modo de afastar e evitar os incômodos mypiri (os flebótomos): como nos contaram alguns velhos, eles usam fumaça, por vezes queimando pimenta, uma ação semelhante ao ato de vingança xamânica que pode atingir inimigos a quilômetros de distância.

Em suma, como extensões metamorfoseadas de inimigos canibais (ãpã porosu'u), morcegos e insetos hematófagos figuram em um nível de hiperalteridade no universo wajãpi, podendo sofrer uma matança desmedida - o extermínio. Algo que remete à forma social que a relação assume entre os Wajãpi, assim como no caso awa-guajá descrito por Garcia (2015, p. 106):

Quando os Awá dizem que os carrapatos e as baratas só vivem a partir desses jaras [donos cosmológicos], de forma diversa da nossa, estão enfatizando que aquilo que nós chamamos de "praga" é para eles um descontrole de outra ordem, de uma ordem sociológica, na qual a relação entre não humanos pode ser pensada como são pensadas as relações entre pessoas, e não como um desequilíbrio ambiental. 
A noção de inimigo e a agressão violenta como uma forma da relação com entes que ocupam essa posição, tal como formulada pelos wajãpi e outros grupos ameríndios, será aqui tomada de modo reverso para delinear que a distância pode ser um marcador importante na gestão das relações mortíferas que nós (exclusivo) perpetramos com alguns seres. Algo que guiará as descrições e a análise que se seguem, intuindo a possibilidade de pensar e fazer render uma noção de espécie inimiga.

\section{O dilema da boa morte}

A distância, como marca de alteridade, é uma relação fundamental na constituição do homicídio. Isso entre grupos tupi, em especial, rendeu grandes análises antropológicas sobre a posição ontológica do outro na relação matador-vítima. Basta lembrar a célebre cena descrita por Hans Staden em que o líder tupinambá, Cunhanbebe, se apresenta como onça no ritual antropofágico, estabelecendo diferença e distância em relação à vítima humana. Tal proposição vem desde o marcante trabalho de Florestan Fernandes (2006), passando por Manuela Carneiro da Cunha e Viveiros de Castro (1985) e recentemente pelo trabalho etnográfico de Camila de Caux (2015) que demonstra a atualidade e a transformação do problema do homicídio entre os Araweté.

Se minha hipótese está correta, de que o que imputa a possibilidade de extermínio $^{15}$ para os Wajãpi é a condição de hiperalteridade dos morcegos e mosquitos hematófagos por decorrência de sua origem e do comportamento canibal atual, gostaria de refletir de modo reverso sobre como um gradiente e uma questão de alteridade podem ter operado também nas coletas e comportamentos de nossa equipe de pesquisa.

15 Me parece aqui que ainda que o desejo de matar animais incômodos aos humanos possa ser amplamente difundido, há duas especificidades nesse caso: 1) falar de uma morte absoluta desses entes, extermínio; 2) que os próprios Wajãpi explicitam e enfatizam a ação canibal desses animais, o que lhes causa uma repulsa específica e acentuada, de forma que minha leitura e análise estão fundadas nessa correlação que, por sua vez, pode ser compreendida em narrativas, ainda que elas não tenham sido diretamente evocadas por meus interlocutores para formular uma explicação. 
As coletas de flebotomíneos foram feitas em sucessivas idas a campo, tanto em aldeias em que os casos da doença eram presentes como naquelas em que eram ausentes. Ao todo são conhecidas mais de mil espécies de flebotomíneos e aproximadamente 30 espécies ou subespécies são vetores comprovados de parasitas do gênero Leishmania (Rangel; Lainson, 2009). Buscava-se com a coleta verificar onde a presença de vetores era mais significativa e, assim, tentar desenhar um modelo de como e onde alguns Wajãpi poderiam estar se expondo ao ciclo de transmissão da doença. ${ }^{16}$ Após capturados, os flebotomíneos eram separados em machos e fêmeas, e acondicionados em solução que preserva a integridade do DNA ou em álcool para seguirem ao laboratório, onde seriam identificados ao nível de espécie. A maior parte das fêmeas (por serem elas que se alimentam de sangue) foram testadas para a presença de Leishmania através de um ensaio com marcador molecular que reconhece fragmentos de DNA do protozoário. Quando houve sangue no trato digestivo, tentaram também fazer análises moleculares para definir quais animais estavam sendo preferidos pelas fêmeas dos insetos; buscávamos uma pista de quais mamíferos poderiam estar atuando como reservatórios mais significativos no ciclo local de transmissão.

Ao todo foram coletados cerca de 5000 espécimes (indivíduos) de flebotomíneos, sendo que as armadilhas também capturavam outros artrópodes atraídos pela luz, os quais eram separados nas triagens diárias. Durante tal processo jamais houve qualquer reflexão ou questionamento sobre a matança (sempre feita com éter) ${ }^{17}$ dos insetos.

Devido à complexidade do ciclo da doença, que tem como reservatório do parasita a fauna de mamíferos (mastofauna), o projeto previu e destacou a necessidade de investigar a presença de leishmânia em animais que

16 O epidemiologista chama atenção de que o modelo foi desenhado também com a participação de alguns Wajãpi. Há um reconhecimento do projeto e da equipe de que os Wajãpi detêm um conhecimento refinado sobre o ambiente em que vivem e acerca das relações ecológicas que travam com uma miríade de seres. Assim, foram amostrados locais que os Wajãpi identificavam como espaços com maior potencial de transmissão.

17 A morte aqui também segue regras protocolares que, nesse caso, preocupa-se com a integridade corporal do inseto (importante para fins taxonômicos), mas que também pode passar por uma questão ética de pensar o que seria uma boa morte para tais animais. 
poderiam operar como reservatórios. Para tanto, era preciso fazer um levantamento da mastofauna em cada local e realizar coleta de tecidos para a análise molecular.

Tal procedimento necessitaria a captura dos animais, sedação, coleta de material e posterior soltura dos mesmos. Atividade que se mostrava inviável, não só pela quantidade de trabalho e especialistas a serem envolvidos, mas igualmente pela difícil captura de animais silvestres em um ambiente tão vasto e com tantos recursos alimentares disponíveis. Em uma experiência anterior na TIW um veterinário tentou capturar cutias para um projeto fomentado por algumas famílias que desejavam criá-las como alternativa à escassez de caça. Durante meses a fio nenhuma única cutia (Dasyprocta leporina) foi pega nas armadilhas espalhadas pelas roças mais devastadas por esses roedores. A baixa taxa de captura de animais na Amazônia é algo amplamente documentado entre biólogos (Lacher Jr. e Claber, 2001) e hoje motivo de piada na TIW.

Frente a esse quadro chegamos a algumas alternativas. Uma delas foi aproveitar a caça abatida pelos Wajãpi para retirar amostras de tecido, procedimento que só pode ser realizado após uma ampla conversa e participação da comunidade. Esse aspecto da pesquisa foi tratado com todo cuidado devido à rígida legislação que envolve pesquisa com amostras biológicas, de um lado, e, de outro, as atividades em terra indígena. O cuidado para que as coisas fossem feitas de forma legal e consentida por todos os envolvidos foi uma constante e por isso muitas conversas e explicações foram realizadas com os nossos principais interlocutores - os agentes de saúde indígena que realizaram majoritariamente essa entre outras ações.

Chegando-se a um acordo e entendimento sobre a relevância dessas amostras, alguns desses jovens wajãpi se engajaram na coleta. Junto com eles foi elaborado um pequeno questionário de identificação de amostras, bem como um rápido treinamento de como fazer o procedimento seguindo protocolos que visavam minimizar o risco de contaminação do tecido animal com células do coletor. Os pequenos frascos com pele eram armazenados na geladeira do laboratório do posto de saúde do polo-base, para serem enviados, juntamente com amostras de sangue fixadas em papel filtro, ao laboratório.

Outra alternativa encontrada para amostrar a fauna em sua diversidade e quantidade foram armadilhas fotográficas - máquinas que possuem um sensor e capturam imagem quando algo se movimenta dentro do seu raio de visão. Em 
seu primeiro uso, os equipamentos foram colocados em alguns dos pontos de coleta de flebotomíneos. Pretendíamos verificar quais animais frequentavam o local, sendo possíveis reservatórios de parasita, uma vez que poderíamos ligar espécies de mamíferos à espécies de flebotomíneos. ${ }^{18}$

Na literatura sobre leishmaniose há referências (Arias et. al., 1981) sobre pequenos roedores e marsupiais operando como relevantes reservatórios do parasita. Havia, por isso, a necessidade de tentar amostrar indivíduos desses grupos com especial atenção. Por tal motivo foi planejada a realização de um campo onde tentaríamos capturar roedores em uma das aldeias em que trabalhamos.

Utilizando armadilhas de tipo Sherman, 50 delas foram espalhadas na aldeia Boa Vista e, contrariando as expectativas de baixa taxa de captura, logo na primeira tentativa foram pegos quatro indivíduos de espécies distintas de Rodentia. Cada um deles foi sedado para a retirada de amostras de tecido e sangue, conforme protocolo aprovado por licença emitida pelo Sisbio/ICMBio. Em seguida eles foram mortos (por overdose de anestésico, seguindo padrões e protocolos de abate). Armazenados em álcool, seriam levados para serem identificados por uma taxonomista.

O primeiro espécime de cada espécie coletada em uma pesquisa, como me explicaram, deve ser abatido e guardado, não só por finalidade de identificação taxonômica, mas como provas do procedimento. Tais amostras são, por isso, designadas em uma coleção como "espécime testemunho". Assim, não havia outro destino a não ser a morte para aqueles primeiros roedores capturados. Contudo, uma série de dificuldades surgiu.

Quem estava responsável por anestesiar e administrar a overdose aos animais era a veterinária. Sedava-se primeiro para que os animais não ficassem estressados com a manipulação; uma forma de minimizar o sofrimento. Devido às decorrências que tomaram parte nesse dia, creio que a diminuição do sofrimento não diz respeito apenas aos ratos, mas àqueles que se envolvem

18 O epidemiologista chama atenção para o objetivo do método, que vai além daquele resumido aqui: "A ideia do uso das armadilhas fotográficas era, também, tentar caracterizar ambientes e cenários de risco para transmissão da doença, com base em indicadores de diversidade de mamíferos e flebotomíneos de forma conjunta. Isso aliado a formas wajãpi de descrever o ambiente poderia ser útil para abordagens de controle e prevenção tanto cientificas quanto nativas." 
no abate; o ônus ético e moral da morte causa sofrimento também aos executores. Após retiradas as amostras, era aplicada a dose letal. Confirmada a morte, o animal era colocado em um saco plástico para ser conduzido ao local onde estava o recipiente de armazenamento cheio de álcool. Esperou-se realizar o procedimento nos quatro espécimes para levá-los ao recipiente, que por seu peso e conteúdo havia sido guardado no posto de saúde que ficava acerca de uma hora de caminhada da aldeia onde trabalhávamos. Mas um imprevisto apareceu.

O segundo indivíduo a ser manipulado, após receber a dose letal, não morreu. De acordo com a veterinária, talvez pelo seu tamanho - ele era bem maior que os outros ${ }^{19}-$, mas sem dúvida por sua singularidade. Como me foi explicado em conversas posteriores e é corroborado por estudos veterinários, a reação a sedativos e anestésicos pode ter variação individual segundo características próprias e únicas de cada organismo, tais como quantidade de gordura no corpo, a velocidade metabólica e outras características ainda não definidas.

Após vários minutos o roedor se encontrava desacordado, mas vivo. Passou-se a execução dos procedimentos nos outros dois capturados. Finalizados, passada quase uma hora, o tal indivíduo insistia em respirar. Esperava-se pacientemente a morte. Os dedos envoltos em látex verificavam a cada instante os batimentos cardíacos - índices da resistência e da vida. A impaciência irrompeu. Havia urgência para preservar os demais animais em álcool. A angústia promoveu um veredito: "Vamos matar logo e acabar com essa agonia." Ao que se reagiu: "Calma, deixa a anestesia matar!"

A tensão e o aperto no peito aumentaram. Quem agonizava agora era a equipe humana. $\mathrm{O}$ dia nublado e úmido deixava o ar pesado. $\mathrm{O}$ silêncio se fazia

19 Ao ler essa explicação, inspirada nas conversas que tivemos sobre o caso, a veterinária insistiu que não se trata exatamente de uma diferença de tamanho, mas que estamos diante de uma cadeia de variáveis mais extensas. Cada indivíduo é único e singular, por isso a reação à substância injetada pode variar de modo não previsto e por condições que não podem ser determinadas de modo simples. O epidemiologista, que também é veterinário, apontou para um sentido similar, mas explorou em sua explicação o procedimento de generalização da ciência que visa tornar protocolos factíveis em qualquer lugar. Segundo o epidemiologista, as próprias características da espécie podem determinar uma maior resistência a um determinado fármaco, mas como é impossível ter um protocolo específico para cada espécie de roedor, esse tipo de situação é comum. Em suma, me parece que estamos diante de fenômenos complexos, com variáveis múltiplas que não podem ser controladas como intentam os procedimentos realizados em laboratório - o recinto, para usar a expressão precisa de Marras (2009). 
à espera da morte. Ela afastava os insetos pacientemente e verificava o pulso, que se tornava cada vez mais lento. Eles se aprontaram para ir ao posto de saúde e já carregavam nos sacos plásticos os outros três roedores mortos. Mas aquele teimava em retardar. Impunha seu tempo de morte. Persistia na vida. Insistiu-se: "Vamos acabar com essa agonia." O outro lado foi taxativo: "Eu vou esperar ele morrer e se não morrer eu vou deixar ele ir..." "Mas ele vai voltar todo detonado dessa anestesia." "Ele vai voltar que nem a gente volta... vai ficar meio lento, mas depois volta ao normal..." Parte de nós nada disse ou interferiu, dando sua sentença. Eu me abstive, concordando com a decisão que fosse tomada, mas minha cabeça de etnóloga que convive com os Wajãpi há mais de uma década pensava: "Nossa, o que esse bicho vai contar se voltar para casa dele..." Silêncio, espera, angústia, discordância, e a morte foi feita. Os espécimes foram então levados e acondicionados, transformando-se de vez em amostras, em testemunhos.

Baixada a tensão, conseguimos conversar. Havia um ponto pacífico: não seria mais possível proceder daquela maneira. Não estávamos, em muitos sentidos, preparados para aquele tipo de procedimento. Concordamos que nos dias que se seguissem os animais capturados seriam anestesiados para coleta de tecido e sangue, mas não seriam sacrificados, e, sim, soltos. Todavia, nos cinco dias de trabalho subsequente apenas no último capturamos um único rato, que durante a manipulação conseguiu empreender fuga.

Se os milhares de insetos capturados ao longo dos diversos campos não suscitaram nenhum debate sobre morte e sacrifício (modo como foi referido o óbito desses mamíferos capturados), eu me perguntava por que a situação com os roedores causou tamanho imbróglio. Qual era a diferença que estava em jogo? Coloquei a questão à equipe, que prontamente me respondeu que os insetos não possuíam um sistema nervoso central e, sem consciência da morte, não sentiriam dor ou expressariam sofrimento, por isso matá-los não exigia procedimentos morais. Já roedores e mamíferos de modo geral, muito pelo contrário, sentem dor, expressam sofrimento e medo, o que implicava a necessidade de um sacrifício - uma morte mediada por anestésico.

Traduzindo nos termos de Donna Haraway (2011), poderíamos entender que a capacidade de resposta (que em um jogo de palavras ela designa como responsabilidade) do roedor foi amplamente reconhecida por nós. Não se tratava de pena ou partilha de sofrimento por meio de uma imaginativa troca de lugares com aquele animal, mas de perceber ações que se davam à revelia do controle 
previsto nos protocolos de pesquisa. Estávamos imersos em uma densa rede de relações, era necessário negociar e reagir de forma não prevista, seguindo uma dinâmica imposta por aquele sujeito roedor repleto de responsabilidade e que exigia de nós responsabilidade.

\section{Primeiro movimento de reversibilidade: a hiperalteridade e sua matabilidade}

Alguns antropólogos têm se debruçado sobre as relações humanos-insetos, e segundo uma das referências nesse campo, Hugh Raffles (2010, p. 3260, tradução minha), os insetos são uma alteridade extrema: "O pesadelo do conhecimento e o pesadelo do não reconhecimento." Nas palavras Uli Beisel, que vem estudando projetos sobre a malária: "Insetos são inextricável e intimamente completamente outros" (Beisel; Kelly; Tousignant, 2013, p. 3, tradução minha). Seres rastejantes, larvas fervilhantes, entes munidos de exoesqueletos que esmagados liberam entranhas viscosas, vetores de patógenos, repleto de olhos, atraídos por cheiros pútridos, hematófagos, zunidores... Em suma, seres que costumam despertar, de um modo geral, asco e desejo de distância. Em nosso jargão aqui empregado, podem ser considerados uma hiperalteridade, como sugere a epígrafe de Vilém Flusser e Louis Bec.

Aqui, a equipe de pesquisa parece aproximar-se dos Wajãpi. Nós (exclusivo) nos assemelhamos a eles. A matabilidade de um ser é diretamente proporcional à sua distância, ao seu grau de alteridade e não reconhecimento de semelhança. Matar insetos não nos levou a crises de consciência e dilemas morais, já roedores... Nossos parentes evolutivamente mais próximos, que coocupam a classe Mammalia, compartilham não só fisiologia e morfologia similares às do Homo sapiens, como também reconhecemos neles comportamentos típicos da posição de sujeito: medo, dor e sofrimento. Tudo gera identificação. Olhar nos olhos de outro ser e matá-lo tem implicações, não se pode fazê-lo de qualquer forma. Por isso há metodologias e protocolos científicos rígidos, meios técnicos para tentar negociar e resolver o ônus moral advindo de tal ato.

Se no mundo wajãpi não há problemas no extermínio de entes como os inimigos canibais, morcegos e insetos hematófagos, resolvendo-se o conflito pelo extermínio, em relação a outros seres há uma série de implicações no matar, 
exigindo igualmente protocolos e cuidados, algo que Gallois (1988) chamou de "ética da moderação". Uma caça alvejada deve ser implacavelmente perseguida até a morte. Se uma anta, um veado ou qualquer mijarã ("caça") é atingido e escapa, o caçador regressa apavorado, assombrado pela vingança de mijarajarã, o dono cosmológico da caça que zela por sua gente-anta, gente-veado, etc. Bravo por ver sua cria machucada, sangrando e sofrendo, o dono envia doenças e outras sortes de agressões que recaem sobre o caçador descuidado. Alguns seres e donos são ainda por demais perigosos para serem ou terem suas criações mortas. Matar uma sucuri (Eunectes ssp.) é um problema grave. Identificada ao dono das águas (yyjarã), sendo ela própria uma manifestação corpórea de yyjarã, a sucuri é um dos mais agressivos e temidos donos e por isso se evita ao máximo matá-la. Quanto aos frondosos angelins (Dinizia excelsa), há restrições em derrubá-los. Essa portentosa árvore é morada de donos bravos e raivosos, por isso ao fazer uma roça seus exemplares podem ser deixados intactos no meio dos roçados.

Se todo o procedimento com os roedores não chamou a atenção ou incomodou os moradores da aldeia, isso não foi por conta de achar que eles poderiam ser manipulados daquela maneira, mas porque a agressão vingativa dos donos recairia sobre aqueles que executavam a ação - nós exclusivo. Qualquer impropério cometido no procedimento seria devidamente resolvido com anujajarã ("dono dos ratos"). Mantendo distância, não haveria qualquer consequência para eles. Talvez por essa razão preferiram ignorar completamente o que fazíamos. Não demonstraram curiosidade, à exceção das crianças, que foram rapidamente afastadas.

Ao fim de nossa estada nessa aldeia, a entomóloga contou ao anfitrião um sonho que havia tido: "Essa noite sonhei que estava num restaurante e que o garçom trazia um prato só de calabresa, como as calabresas que usamos de isca nas armadilhas dos roedores." Ao que o velho wajãpi concluiu: “É... anujajarã está te pegando, tá te transformando... Você já tá pegando o jeito dele [de roedor]."

O sonho, kerãpe - literalmente o "caminho do sono" -, é um dos meios de acesso e comunicação com o universo paralelo dos donos, onde e quando eles aparecem em sua forma e socialidade humanas. Agressões, negociações, relações sexuais, conhecimentos e outras formas de relação com os ijarã ocorrem pela via onírica, momento em que o princípio vital -'ã se descola do invólucro corporal e passeia por outros mundos. Uma das agressões dos ijarã é o roubo-sedução do princípio vital -'ã, ação que pode gerar vários sintomas e que, em 
seu estágio final (se não houver uma intervenção xamânica de recuperação do -'ã), acarreta a transformação completa em gente-rato, gente-sucuri, e assim por diante, dependendo de quem profere o roubo. Completar a transformação e habitar o mundo de uma gente-bicho implica morte para seus parentes. O velho wajãpi anunciava a possível consequência do trabalho com os roedores: transformar-se em gente-rato.

Mas as consequências do empreendimento científico de coleta dos ratos não eram apenas de ordem moral. Como fiquei sabendo durante todo o procedimento, eu, assim como as crianças curiosas, fomos orientadas a ficarmos distantes do local onde realizavam o manuseio dos animais. Os roedores são hospedeiros de diversos patógenos, alguns deles podendo ser transmitidos por via aérea. Por essa razão, todos que participam da atividade devem estar munidos de máscara, luvas e ter todo cuidado, seguindo protocolos rígidos para evitar contaminação. Ainda que de modo distinto, assim como entre os Wajãpi, as implicações de coleta também perpassam por ônus corporais e físicos no nosso mundo, podendo implicar doença e morte.

\section{Segundo movimento de reversibilidade: armadilhas e metamorfose}

Voltando ao problema metafísico anunciado por nosso anfitrião - a possível metamorfose em rato da entomóloga -, outro caminho para pensar essa questão é o dispositivo da armadilha e a ação de captura.

Ao buscar repensar o conceito de arte a partir de exemplos etnográficos de armadilhas de caça, Alfred Gell (1996) apresenta ideias interessantes acerca desses potentes objetos. Segundo o autor as armadilhas não são apenas instrumentos tecnológicos, mas modelos. São modelos de ação de seus construtores, uma vez que emulam uma série de atos do caçador (como o disparo de uma arma de fogo, o flechar, o enlaçar, etc.), e são modelos do ambiente e comportamento das vítimas, já que imitam a Umwelt (para falar com Von Uexküll, 1934) da presa. Gell nos alerta: obviamente a emulação da Umwelt não é algo intrínseco ao objeto, mas é um conhecimento do caçador sobre o comportamento-ambiente da presa, que ele traduz em uma materialidade cheia de artimanhas. As armadilhas sedimentam e condensam as complexas relações entre caçador, presa e ambiente. 
Ann Kelly (2012), ao acompanhar um estudo sobre malária na África, leva adiante esse argumento, pontuando que na coleta-captura do vetor da doença - os Anopheles - por meio de abrigos-armadilhas, os pesquisadores lançam mão de um conhecimento refinado sobre comportamentos e ambientes dos mosquitos. Ao conhecerem de modo íntimo a Umwelt dos anofelinos, ela sugere que tais pesquisadores acabam por tornar-se um pouco mosquitos.

Outros antropólogos (Beisel, 2010; Beisel; Boëte, 2013; Hird, 2010) que trabalham com doenças vetoriais têm apontado para como a captura de vetores e o estudo dessas hiperalteridades, os mosquitos transmissores de patógenos, envolvem um conhecimento que advém de uma relação íntima com animais que, normalmente, as pessoas fazem de tudo para evitar, e com os quais a única relação é a morte: seja pela transmissão de doenças deles para nós, seja pelo nosso desejo de matá-los a tapas ou com inseticidas. Os entomólogos são alguns daqueles que estabelecem outras relações com insetos, e alcançam nesse processo um devir-inseto.

Hugh Raffles (2010) e Uli Beisel (2010) são enfáticos nesse aspecto da metamorfose que o conhecimento entomológico exige. Ao abordar a intimidade de Henry Bates perseguindo insetos floresta afora, Raffles afirma que o famoso naturalista era dotado de "olhos de inseto", pois para conseguir coletar e capturá-los era necessário percorrer e ver o mundo através da corporalidade de besouros, libélulas, mariposas... Beisel nos traz como ilustração do devir-inseto uma bela passagem do diário de Walter Benjamin sobre sua infância, época em que ele colecionava borboletas:

Entre nós, agora, a velha lei da caçada tomava lugar: quanto mais eu batalhava para me adaptar em todas as fibras de meu ser ao animal, mais como-borboleta eu me tornava em minha alma e coração; quanto mais essa borboleta era ela mesma em tudo que fazia, ela aceitava as cores da volição humana; e, no final, era como se sua captura fosse o preço que eu tinha que pagar para retomar minha existência humana. (Benjamin, 2006, p. 51 apud Beisel; Kelly; Tousignant, 2013, p. 2, tradução minha).

O trecho de Benjamin permite perceber como a captura, via armadilha ou caçada, efetua um momento de junção de Umwelten. A captura exige um entendimento minucioso do comportamento-mundo da presa que pode ser 
entendido como uma entrada do algoz na Umwelt da vítima, imersão que é rompida apenas com a morte.

Em nossa pesquisa foram usados dois tipos de armadilhas para coletar flebotomíneos: luminosa e Shannon. Ainda trata-se de um tema controverso, mas a teoria mais aceita é que os flebótomos, assim como outros insetos noturnos, orientam seu voo pela luz da lua e das estrelas. Os astros seriam uma referência para tais seres, que mantêm o voo em um certo ângulo em relação ao céu e ao solo. Tais animais não distinguiriam a luz dos astros das fontes de luminosidade artificial, confundindo-as especialmente em noites de lua nova, quando não há a competição de raios lunares e por isso as taxas de coleta são maiores. Outra hipótese é que a fonte de luz indica um caminho desobstruído fazendo com que o mosquito traçasse a rota de voo em sua direção. Ainda que não haja um conhecimento consolidado sobre a razão dessa atração, o fato é que o interesse de mosquitos por luzes é amplamente reconhecido e usado para pegá-los. A outra armadilha usada foi a barraca de Shannon que, além de luz, atrai insetos hematófagos pelo calor e $\mathrm{CO}_{2}$ dos coletores humanos que funcionam como iscas. ${ }^{20} \mathrm{No}$ caso, fomos eu e a entomóloga que ficamos sob a armadilha, que se caracteriza como uma tenda de tecido branco. Ao pousarem contra o fundo branco, os flebótomos eram reconhecidos e sugados um a um para um tubo coletor. A entomóloga os reconhecia por uma série de características, e tentando ensinar-me mencionou algumas delas: eles têm um voo característico (curto), ao pousarem no tecido deslocavam-se por pequenos saltos, as asas ficam em posição aberta (formando um pequeno V), e há ainda o tamanho pequeno e a cor clara.

Se a barraca de Shannon nos leva de forma mais evidente a um domínio do conhecimento da Umwelt dos flebotomíneos (que são atraídos pelo $\mathrm{CO}_{2}$ ), no caso das armadilhas luminosas isso apareceu em especial no modo de distribuí-las e nos locais escolhidos para amostragem. Alguns lugares são preferidos pelos flebótomos. Insetos diminutos, sensíveis ao sol e a locais abertos onde secariam até a morte, eles nutrem um gosto por espaços repletos de matéria orgânica e umidade, tais como: troncos caídos em estágio de decomposição; árvores

20 Segundo me aconselhou e informou a entomóloga, o termo "isca" não deve mais ser usados nos artigos científicos de entomologia. Todavia, optei por mantê-lo, pois ele explicita uma relação de assimetria invertida, uma vez que os humanos se tornam objetos de atração e assumem um risco (lugar comumente ocupado por animais nos experimentos). 
de casca grossa e rugosa, como os angelins; e buracos de tatu (Dasypus ssp.). Poderíamos dizer, aliás, que os flebótomos são espécies companheiras dos tatus, conhecimento compartilhado tanto pela equipe científica como pelos Wajãpi, que também designam os flebótomos de tatukyy, que poderíamos traduzir como "piolho de tatu" ou "parasita companheiro de tatu". Assim, as armadilhas eram colocadas nos locais de preferência ${ }^{21}$ dos flebotomíneos.

Mas o interesse da entomóloga não se restringia a essa subfamília da ordem Diptera. Em todos os nossos deslocamentos pela TI, ela observava insistentemente os mais diversos invertebrados que cruzavam nosso caminho. Às vezes saía com seu inseparável puçá e capturava mariposas, mosquitos, abelhas e besouros. Olhava-os de perto e depois os soltava. Seu encantamento era contagiante e aos poucos, quando me deparava com algum inseto, chamava-lhe atenção e aprendia algo sobre seu nome e comportamento. Esse interesse, que eu aprendi a nutrir acompanhando-a, possibilitou mais uma conexão entre nós. Foi numa de nossas viagens de barco (quando uma série de aranhas, formigas e besouros costumam cair sobre os tripulantes, devido à proximidade da mata ciliar que abraça os pequenos igarapés da TIW) momentos em que apertávamos os olhos, tentando focar e observar formas, cores e modos de locomoção daqueles pequeninos seres, que ela me disse: "Sabe, Joana, os insetos são um outro mundo!" Enfatizando a questão da diferença de escala espaçotemporal

21 A entomóloga também me alertou sobre a inadequação desse termo: "Para insetos não usamos 'preferência', mas 'ocorrência." Essa controvérsia me parece estar assentada justamente na distância ontológica entre humanos e insetos, e por sua vez entre mamíferos e insetos, sendo os últimos colocados em um lugar da ausência de volição, consciência ou cognição. Insetos não preferem nada, apenas ocorrem em um lugar ou outro, assim como os acidentes geográficos ocorrem em uma paisagem. O que está em jogo segundo ela são processos evolutivos de seleção natural e adaptação, em que não há agência alguma: "Existem mecanismos que atuam no tempo e no espaço que levam ao surgimento de acidentes geográficos e também de adaptação dos organismos a determinadas condições. Não há agência nem nos insetos, nem em nós, assim, não é que quero me distanciar dos insetos, mas acho que somos todos fruto de um determinismo que não permite escolhas no sentido de ter livre-arbítrio." O epidemiologista por sua vez pareceu ficar em dúvida quanto a essa discussão, observando o seguinte: "Entendo que existe preferencia, sim, mosquitos têm preferencia por picarem determinadas espécies em vez de outras, por exemplo. Além disso, todos os seres têm um mínimo de consciência, isso pode ser visto ao observarmos que mosquitos podem ser agressivos pela busca do repasto, e muitos insetos nitidamente percebem o perigo quando tentamos mata-los." Optei por deixar essa formulação, bem como outras nesse parágrafo, que buscam uma narrativa que coloca os flebótomos na posição de sujeitos, uma inspiração na filosofia wajãpi que permite evidenciar uma fragmentação do nosso nós, proliferando divergências internas. 
entre nós (inclusivo) e eles, ela me falava com entusiasmo sobre os microcosmos: "Tem insetos... gerações de insetos que nunca saem da mesma árvore! Esse microambiente é um mundo para ele!"

Em meio a uma discussão dentro da antropologia não preciso chamar a atenção para como as afirmações de minha colega ressoam com o perspectivismo (Lima, 1999; Viveiros de Castro, 2002). Todavia, estamos muito distantes de uma reflexão sobre a humanidade compartilhada. Trata-se apenas de um interesse vívido e legítimo em outras formas de vida. Interesse que conduz a um conhecimento minucioso capaz de gerar uma imaginação acerca das Umwelten desses outros outros, e de compreendê-los como dotados de um mundo próprio. Uma capacidade de imaginar distintos mundos que, ao contrário do modo de conhecer xamânico - que opera no universo wajãpi - não gera a possibilidade física de transformação em outro, em algum inseto, mas pressupõe um conhecimento que permite um deslocamento imaginativo entre universos. A atenção localizada e focada por um instante de observação ou captura pode significar uma metamorfose epistemológica, na medida em que permite um conhecimento e uma experiência imaginativa sobre outra Umwelt.

Note-se que Von Uexküll (1934), ao buscar dar expressão aos "mundos fenomenológicos" e aos "universos subjetivos" dos animais, desenvolve o conceito de Umwelt (ambiente-organismo/mundo-sujeito) - cujo exemplo mais afamado é o do carrapato (espécies da ordem Ixodida). O mundo do carrapato é composto por dois estímulos: a fragrância do suor e o calor dos animais de sangue quente. Na teoria de Uexküll só há mundo percebido por um sujeito, pressuposição que gera a nossa familiar proposição perspectivista da multiplicidade de naturezas. Mas, na teoria do naturalista, o conhecimento do mundo do outro é sempre opaco. Afinal a posição transespecífica do xamã não está presente. Talvez quem mais se aproxime da posição do xamã é o cientista, que por meio do estudo do comportamento animal infere os possíveis mundos habitados por tantas alteridades animais. Em minha leitura, na teoria de Uexküll não haveria um conhecimento pleno das Umwelten, apenas esboços inferidos por sinais e comportamentos sobre os quais voltamos uma atenção minuciosa.

O velho wajãpi teme e alerta para uma possibilidade de metamorfose plena; as armadilhas ao jogarem com a mimese e o engodo operam passagens entre mundos; e a entomóloga viaja pelos microcosmos dos insetos, assim como Benjamin ou qualquer outro fascinado por insetos faz na tentativa de capturar 
borboletas. Todos esses episódios e técnicas tratam de momentos fugazes e de diferentes intensidades de conformação e comunicação entre Umwelten que são instantaneamente quebrados pela morte.

\section{Sobre espécies inimigas}

Trabalhar com doenças zoonóticas nos leva a uma reflexão sobre as relações interespecíficas em diferentes níveis. No caso em pauta, entre os protozoários e os mamíferos reservatórios, os flebotomíneos que transportam o patógeno e convivem com a mastofauna e com as famílias wajãpi. Falar de relações interespecíficas na antropologia remete de imediato a Donna Haraway (2003a, 2003b) e seu conceito de espécie companheira. A noção de espécie companheira é fundamental na constituição da vida de um modo geral e na gênese humana - espécie que tradicionalmente interessa aos antropólogos. Os exemplos elencados pela autora vão desde as bactérias que habitam nossos intestinos, possibilitado absorção de nutrientes, até animais de estimação, que fazem parte do convívio íntimo e afetuoso. Ainda que o conceito não se funde no amor e em relações mutualistas - e Haraway é clara quanto a isso - é nesse campo das relações afetuosas e de mútuo inter-esse com efeitos positivos que a discussão ganhou corpo.

Quem se dedica ao estudo antropológico de doenças vetoriais (Beisel; Kelly; Tousignant, 2013) se pergunta qual a possibilidade de estender a noção de espécie companheira para organismos que nos são nefastos. As autoras são relutantes sobre a possibilidade de "tornar-se com" (becoming-with) insetos e patógenos. "Tornar-se com" é uma das proposições que Haraway desenvolve a partir de casos de organismos que nos são benéficos e que nos tornam humanos; fazem parte de nossa ontogênese.

Mas, segundo a própria Haraway (2003a, p. 34, tradução minha), mesmo nossa principal espécie de companhia, o cachorro, não está inserida em um complexo de relações harmoniosas e amorosas: "A saga que se segue [O manifesto da espécie companheira] não é sobre amor incondicional, mas sobre buscar habitar um mundo intersubjetivo, é sobre encontrar a alteridade em todo detalhe visceral de um relacionamento mortal."

O interesse e o desejo wajãpi de exterminar os morcegos; a vontade do epidemiologista de apenas controlar a população desses hematófagos; a controvérsia 
envolvendo a morte do roedor; a preocupação do anfitrião wajãpi de que a pesquisadora estaria virando rato; e o interesse da entomóloga sobre insetos são todos eventos que remetem ao habitar um mundo intersubjetivo, mas de formas distintas e próprias. Seria o conceito de espécie companheira produtivo para compreender todas as narrativas apresentadas? Certamente ainda que nos sirva e possibilite uma forma de entendimento, a escolha por descrições complicadas, por um exercício comparativo que tenta suspender uma estabilização constante, não poderia render-se a um uso conceitual sobrecodificante. Inspirada pela fórmula stengeriana, não há solução geral, é preciso compreender os problemas e descrevê-los a cada vez (Stengers, 2017, 2018); em cada cenário comparativo se nuançam diferenças e semelhanças que produzem sentidos.

No caso de nosso projeto de pesquisa, diria que qualquer proposição e entendimento que a pesquisa coletiva resulte, visando o controle da doença na TIW (que hoje como política pública se restringe à aplicação de veneno para matar os vetores), trata-se de um esforço de negociar e de assumir nossa responsabilidade - enquanto habilidade em responder (Haraway, 2011) - em relação a essas diversas intersubjetividades, que fazem parte da complexa epidemiologia da leishmaniose. Mesmo que essa seja uma relação que se estabeleça via doença e morte, a reflexão fragmentada e quase fractal apresentada aqui aponta para a necessidade de encarar e refletir sobre possibilidades de relacionamento.

Podemos ir adiante com o rendimento da ideia de espécie companheira e mesmo transformá-la de maneira reversa. No caso em foco, devido ao efeito nefasto e do óbvio desejo de ruptura da relação com os insetos vetores e com o protozoário, poderíamos designar tais companhias como espécies inimigas. A inspiração vem do meio. De um lado a etnologia das Terras Baixas aponta em diversos trabalhos o rendimento da máxima lévi-straussiana de "abertura ao outro" (Lévi-Strauss, 1993) como uma marca do pensamento ameríndio de modo geral e tupi em específico. Como mostrou o velho mestre e tantos de seus seguidores, estamos diante de uma socialidade que se faz por relações centrípetas, onde a alteridade mais do que constituinte é necessária ao socius. Por outro lado, tomando o viés da coevolução (conceito central à Haraway), a relação entre distintos organismos é fundamental na gênese da vida e das espécies, as quais só podem ser pensadas em meio a um emaranhado de relações que evoluem (Thompson, 1994).

A gênese de nossas espécies inimigas passam por convivências íntimas e complexas com outros organismos (sendo o Homo sapiens uma espécie entre 
outras). Convivências nem sempre benéficas aos envolvidos, mas que possibilitaram evolutivamente que a leishmânia percorresse esse longo caminho para infectar seu hospedeiro último - os humanos. Estudos recentes de coevolução holobionte - unidade evolutiva que engloba todos os tipos de associação simbiótica (Dheilly, 2014) - demonstram que hospedeiros e parasitas produzem alterações mútuas no fenótipo e genótipo dos organismos associados, que podem acarretar desde uma diminuição na virulência dos parasitas até a modificação de flora microbiótica do hospedeiro. Um constante processo de coevolução antagonística (Dheilly; Poulin; Thomas, 2015). Se estendemos a rede ecológica no tempo, podemos pressupor que foram longos processos de convivências, co-histórias e amálgamas entre leishmânia, flebótomos, mastofauna e humanos.

Outra possibilidade de interpretação complementar é, sem dúvida, pensar a relação de espécie companheira de modo perspectivista (Viveiros de Castro, 2002). Pensando no desejo wajãpi de extermínio dos morcegos em oposição à nossa equipe de pesquisa e sua preocupação com o equilíbrio das relações ecológicas, questionei a entomóloga acerca das possíveis consequências de um extermínio completo dos flebótomos. Recebi a resposta em tom cômico: "Acho que o único grande impacto seria para as leishmânias. Os flebotomíneos, provavelmente, não são tão importantes de forma que o seu sumiço produzisse um efeito em cascata desastroso para outros organismos. Não são fonte importante de alimentação para outros organismos, suas larvas participam da ciclagem de nutrientes no solo como muitos outros organismos e ninguém ia sofrer se eles parassem de sugar sangue."22 Se esses hematófagos são um estorvo para nós e

22 É preciso ter em vista que, como em qualquer trabalho de campo na antropologia, nossos interlocutores formulam respostas momentâneas para nossas questões. Quando o trabalho é posto à prova a esses interlocutores novas compreensões e respostas são formuladas. O epidemiologista chama atenção para que a resposta da entomóloga não está fundamentada em pesquisas sobre esse tema, pois elas não foram realizadas. Ele pondera que existem infinitas possibilidades de relações ecológicas complexas. O papel exercido pelos flebótomos como moduladores de infecção de parasitas entre diferentes espécies determina uma pressão de seleção. A supressão dos flebotomíneos poderia permitir um grande incremento de alguma espécie que antes era controlada pela infecção constante de um parasita. Ainda assim, me parece que a entomóloga em sua resposta joga com as possibilidades de diferentes perspectivas no que concerne aos desdobramentos ecológicos, o que aponta para a complexidade em jogo nesses sistemas. Além disso, a entomóloga ecoa a posição majoritária de outros pesquisadores, tal qual apresentada por Fang (2010). Note, como apontado na nota 12, que há um desacordo, uma controvérsia, que é interna ao nós (exclusivo), a qual não pude explorar de modo detido, mas fica aqui registrada. 
nos fazem adoecer, são nossas espécies inimigas, conduzindo ao desejo de apenas cortar qualquer relação que podemos vir a ter com eles, os flebotomíneos são as espécies companheiras por excelência das leishmânias e quiçá de entes vegetais, uma vez que os machos se alimentam de sumos de plantas.

\section{Referências}

ARIAS, J. R. et al. The opossum, Didelphis marsupialis (Marsupialia: Didelphidae), as a reservoir host of Leishmania braziliensis guyanensis in the Amazon Basin of Brazil. Transactions of the Royal Society of Tropical Medicine and Hygiene, v. 75, n. 4, p. 537-541, 1981.

BEISEL, U. Jumping hurdles with mosquitoes?. Environment and Planning D: Society and Space, v. 28, p.46-49, 2010.

BEISEL, U.; BOËTE, C. The flying public health tool: genetically modified mosquitoes and malaria control. Science as Culture, v. 22, n. 1, p. 38-60, 2013.

BEISEL, U.; KELLY, A. H.; TOUSIGNANT, N. Knowing insects: hosts, vectors and companions of science. Science as Culture, v. 22, n. 1, p. 1-15, 2013.

CANDEA, M. On two modalities of comparison in social anthropology. L'Homme, n. 218, p. 183-218, 2016.

CARNEIRO DA CUNHA, M.; VIVEIROS DE CASTRO, E. Vingança e temporalidade: os Tupinambá. Journal de la Société des Américanistes, Paris, v. 71, n. 1, p. 191-208, 1985.

CAUX, C. de. O riso indiscreto: couvade e abertura corporal entre os Araweté. 2015. Tese (Doutorado em Antropologia Social) - Museu Nacional, Universidade Federal do Rio de Janeiro, Rio de Janeiro, 2015.

DHEILLY, N. M. Holobiont-holobiont interactions: redefining host-parasite interactions. Plos Pathogen, v. 10, n. 7, e1004093, July 2014.

DHEILLY, N. M.; POULIN, R.; THOMAS, F. Biological warfare: microorganisms as drivers of host-parasite interactions. Infection, Genetics and Evolution, v. 34, p. 251-259, Aug. 2015.

FANG, J. A world without mosquitoes. Nature, v. 466, p. 432-434, 2010.

FERNANDES, F. A função social da guerra na sociedade tupinambá. São Paulo: Biblioteca Azul, 2006. 
FLUSSER, V.; BEC, L. Vampyroteuthis infernalis. São Paulo: Annablume, 2011.

GALVÃO, L. A. C.; FINKELMAN, J.; HENAO, S. Determinantes ambientais e sociais da saúde. Rio de Janeiro: Editora Fiocruz, 2011.

GALLOIS, D. T. O movimento na cosmologia Waiãpi: criação, expansão e transformação do universo. 1988. Tese (Doutorado em Antropologia) - Faculdade de Filosofia, Letras e Ciências Humanas, Universidade de São Paulo, São Paulo, 1988.

GARCIA, U. Sobre o poder da criação: parentesco e outras relações Awá-Guajá. Mana, Rio de Janeiro, v. 21, n. 1, p. 91-122, 2015.

GELL, A. Vogel's net. Traps as artworks and artworks as traps. Journal of Material Culture, v. 1, n. 1, p. 15-38, 1996.

HARAWAY, D. The companion species manifesto: dogs people and significant otherness. Chicago: Prickly Paradigm Press, 2003a.

HARAWAY, D. When species meet (posthumanities). New York: Paperback, 2003b.

HARAWAY, D. A partilha do sofrimento: relações instrumentais entre animais de laboratório e sua gente. Horizontes Antropológicos, Porto Alegre, ano 17, n. 35, p. 27-64, jan./jun. 2011.

HIRD, M. J. Meeting with the microcosmos. Environment and Planning D: Society and Space, v. 28, p. 36-39, 2010.

HOUAISS, A. Dicionário Houaiss da língua portuguesa. Rio de Janeiro: Objetiva, 2001.

KELLY, A. The experimental hut: hosting vectors. Journal of the Royal Anthropological Institute, v. 18, n. s1, p. S145-S160, 2012.

LACHER Jr., T. E.; CLABER, J. R. A. Terrestrial small mammal richness and habitat associations in an Amazon forest-cerrado contact zone. Biotropica, v. 33, n. 1, p. 171$181,2001$.

LÉVI-STRAUSS, C. História de lince. São Paulo: Companhia das Letras, 1993.

LIMA, T. S. Para uma teoria etnográfica da distinção natureza e cultura na cosmologia jururna. Revista Brasileira de Ciências Sociais, São Paulo, v. 14, n. 40, p. 43-52, 1999.

MARRAS, S. Recintos e evolução: capítulos de antropologia da ciência e da modernidade. 2009. Tese (Doutorado em Antropologia) - Faculdade de Filosofia, Letras e Ciências Humanas, Universidade de São Paulo, São Paulo, 2009.

RAFFLES, H. Isectopedia. New York: First Vintage, 2010.

RANGEL, E. F.; LAISON, R. Proven and putative vectors of American cutaneous leishmaniasis in Brazil: aspects of their biology and vectorial competence. Memórias do Instituto Oswaldo Cruz, Rio de Janeiro, v. 104, n. 7, p. 937-954, 2009. 
STENGERS, I. Reativar o animismo. Belo Horizonte: Chão de Feira, 2017. (Cadernos de Leituras n. 62).

STENGERS, I. A proposição cosmopolítica. Revista do Instituto de Estudos Brasileiros, n. 69, p. 442-462, abr. 2018.

STRATHERN, M. O gênero da dádiva. Campinas: Ed. Unicamp, 2006.

THOMPSON, J. N. The coevolutionary process. Chicago: The University of Chicago Press, 1994.

VIVEIROS DE CASTRO, E. A inconstância da alma selvagem. São Paulo: Cosac \& Naify, 2002.

VON UEXKÜLL, J. A stroll through the worlds of animals and men. New York: International Universities Press, 1934.

Recebido:13/06/2019 Aceito:14/11/2019 | Received:6/13/2019 Accepted:11/14/2019 